\title{
Changes in the expression of prostaglandin $E$ and $F$ synthases at induced and spontaneous labour onset in the sheep
}

\author{
H K Palliser, G T Ooi ${ }^{1}$, J J Hirst, G Rice ${ }^{2}$, N L Dellios, \\ R M Escalona ${ }^{\mathbf{1}}$ and I R Young \\ Department of Physiology, Monash University, Victoria 3800, Australia \\ ${ }^{1}$ Prince Henry's Institute of Medical Research, Clayton, Victoria 3168, Australia \\ ${ }^{2}$ Department of Obstetrics and Gynaecology, University of Melbourne, Mercy Hospital for Women, East Melbourne, Victoria, Australia \\ (Requests for offprints should be addressed to I R Young; Email: ross.young@med.monash.edu.au)
}

\begin{abstract}
The differential production of prostaglandin $(\mathrm{PG}) \mathrm{F}_{2 \alpha}$ and $\mathrm{PGE}_{2}$ within the uterine compartment may play a role in controlling myometrial contraction. We hypothesized that the enzymes downstream of PG endoperoxide synthase-2 (PGHS-2) determine the ratio of $\mathrm{PGF}_{2 \alpha}$ and $\mathrm{PGE}_{2}$ in the utero-ovarian vein plasma and the time of normal and preterm labour onset. The aim of this study was to simultaneously determine the expression of PGF and PGE synthases (PGFS and PGES) in gestational tissues at spontaneous and induced-preterm labour in sheep. Myometrial, endometrial and placental tissue were obtained from ewes in dexamethasone-induced preterm labour, age-matched control ewes, and ewes in spontaneous term labour for analysis of mRNA expression by real-time PCR. PGFS mRNA expression was significantly increased following dexamethasone-induced and spontaneous labour onset in placentome $(P<0 \cdot 01)$ but was
\end{abstract}

unchanged in the myometrium and endometrium. In contrast, PGES mRNA expression remained unchanged or decreased. PGHS-2 mRNA expression was increased in all tissues examined in both dexamethasone-induced and spontaneous labour $(P<0 \cdot 001)$. Plasma $\mathrm{PGE}_{2}$ and $\mathrm{PGF}_{2 \alpha}$ concentrations rose in both dexamethasoneinduced and spontaneous labour with the ratio of $\mathrm{PGF}_{2 \alpha}: \mathrm{PGE}_{2}$ increased with labour onset $(P<0 \cdot 05)$. These results are consistent with the hypothesis that the increased expression, of PGFS is responsible for the increased $\mathrm{PGF}_{2 \alpha}: \mathrm{PGE}_{2}$ ratio and this, together with increased PGHS-2 expression, accounts for myometrial activity at labour onset. The findings point to PGFS expression as a key factor in regulating the uterotonic process in the sheep.

Journal of Endocrinology (2004) 180, 469-477

\section{Introduction}

Current tocolytic therapies for the treatment of preterm labour are relatively ineffective and may pose risks to the mother and/or fetus. In part, the inability to adequately manipulate labour onset reflects an incomplete understanding of the mechanisms involved in labour. In all mammalian species, including sheep, prostaglandins (PGs) play a crucial role in the initiation of labour. Premature labour follows withdrawal of progesterone, the administration of oestradiol or the increase in plasma PG concentrations, which can also be induced by the administration of glucocorticoid to the fetus (Liggins et al. 1973). The glucocorticoid-infused, chronically prepared ovine fetal model has proved successful for the investigation of new tocolytic therapies (Poore et al. 1999). PGs, specifically $\mathrm{PGF}_{2 \alpha}$, mediate myometrial contractions associated with the onset of labour in both sheep and humans
(Carraher et al. 1983, Wiqvist et al. 1983). Further understanding of the specific regulation of intrauterine PG synthesis may provide a rational basis for the development of new and effective tocolytic therapies.

PGs are synthesized by the action of the enzyme PGH synthase (PGHS), which converts membrane-derived arachidonic acid to $\mathrm{PGH}_{2}$, the common precursor of all PGs. There are two isoforms of PGHS: PGHS-1 is a constitutively expressed enzyme, while PGHS-2 is an inducible form that is upregulated by factors including growth factors and cytokines (Kujubu et al. 1991). PGHS-2 is selectively upregulated during late gestation and parturition in human and ovine gestational tissues (Wimsatt et al. 1993, Hirst et al. 1995, Rice et al. 1995). Furthermore, PGHS-2 mRNA and protein content increase in ovine myometrium, endometrium and placenta during established labour (Rice et al. 1995, McLaren et al. 1996, Zhang et al. 1996a). This marked rise in PGHS-2 
expression and activity is associated with an increase in the concentrations of $\mathrm{PGE}_{2}$ and $\mathrm{PGF}_{2 \alpha}$ in fetal and maternal plasma (McLaren et al. 1996).

An increase in maternal plasma $\mathrm{PGE}_{2}$ concentration is observed from mid-gestation to term, with little further increase during labour (Deayton et al. 1993, Poore et al. 1999, Wu et al. 1999). In contrast, plasma $\mathrm{PGF}_{2 \alpha}$ concentrations do not vary significantly during pregnancy but rapidly increase approximately $24 \mathrm{~h}$ before labour onset (Liggins \& Grieves 1971). Differential $\mathrm{PGE}_{2}$ and $\mathrm{PGF}_{2 \alpha}$ production by the uterus and the increased $\mathrm{PGF}_{2 \alpha}: \mathrm{PGE}_{2}$ ratio in utero-ovarian vein (UOV) plasma, as noted previously in our laboratory (McLaren et al. 1996), is consistent with the hypothesis that mechanisms downstream of PGHS-2 may be pivotal in the labour-associated switch from myometrial quiescence to contractile activity. These observations would imply the differential regulation of PGE and PGF synthase (PGES and PGFS) activities. Elucidating the mechanisms that regulate the terminal PG synthase pathways may provide novel approaches to the suppression of preterm uterine activity.

The direct conversion of $\mathrm{PGH}_{2}$ to $\mathrm{PGF}_{2 \alpha}$ by the activity of PGFS is the predominant pathway for $\mathrm{PGF}_{2 \alpha}$ formation in gestational tissues (Watanabe et al. 1985). This reaction is catalysed by PGH 9,11-endoperoxide reductase activity. Another enzyme, PGE 9-ketoreductase, catalyses the conversion of $\mathrm{PGE}_{2}$ to $\mathrm{PGF}_{2 \alpha}$. However, it has been found that PGE 9-ketoreductase activity is very low in human decidua and the conversion of $\mathrm{PGE}_{2}$ to $\mathrm{PGF}_{2 \alpha}$ is insignificant (Niesert et al. 1986). Of the currently known PGFS genes, the predominant PGF-synthesizing activity is believed to be the direct conversion of $\mathrm{PGH}_{2}$ to $\mathrm{PGF}_{2 \alpha}$ in gestational tissues by PGH 9,11 endoperoxide reductase, which we shall refer to as PGFS in this contribution.

PGES, a member of the protein superfamily consisting of membrane-associated proteins involved in eicosanoid and glutathione metabolism, converts $\mathrm{PGH}_{2}$ to $\mathrm{PGE}_{2}$. PGES was first fully identified and characterized in human cells (Jakobsson et al. 1999) and bovine heart cells (Watanabe et al. 1999). This inducible, membraneassociated form (mPGES) has been reported to be functionally coupled to PGHS-2 expression in the same cells (Murakami et al. 2000). In this study, mPGES was measured due to its association with inducible PGHS-2.

Wu et al. (2001) have recently reported that PGFS mRNA was present but did not change in ovine myometrium, endometrium or placenta in association with spontaneous labour. Betamethasone-induced labour was associated with a significant decrease in PGFS mRNA in the endometrium and maternal placenta with no change seen in the myometrium and fetal placenta. Martin et al. (2002) detected PGES mRNA expression in ovine placentomes from 65 days of gestation until term (147 days), but no significant labour-associated increase was observed. No study has yet examined the relative expression of PGFS, PGES and PGHS-2 mRNA in the same tissues.

The aim of this study was to compare the relative expression of PGFS and PGES mRNA and to simultaneously compare these with PGHS-2 mRNA expression in the ovine myometrium, endometrium and placentome during induced-preterm and spontaneous labour. In accordance with previous studies, a labour-associated increase in PGHS-2 mRNA relative abundance was anticipated. The hypothesis tested in this study was that labour onset is associated with increased PGFS but not PGES mRNA expression. Differential expression of these PG synthases may account for the labour-associated profiles of plasma PGs and yield insights into the relative regulation of $\mathrm{PGF}_{2 \alpha}$ and $\mathrm{PGE}_{2}$ concentrations. We also measured the veno-arterial concentration difference of both these PGs across the uterine vascular bed to confirm that the biological response matched our previous findings and as an indirect measure of the changes in the biological activity of the synthase enzymes.

\section{Materials and Methods}

\section{Animals}

Twelve pregnant Border Leicester-Merino crossbred ewes of known gestational ages (GAs) were used in this study. Experimental procedures were approved by the Institutional Animal Ethics Committee. Ewes underwent surgery at GA 124-127 days in which fetal and maternal carotid artery and jugular vein catheters were implanted. UOV catheters were placed in both horns of the uterus (reported UOV data are from the horn containing the catheterized fetus). Electromyogram (EMG) electrodes were sewn into the myometrium in order to monitor myometrial activity. Fetal arterial plasma was sampled daily to obtain fetal blood gas parameters as a marker of fetal well-being.

The ewes were randomly assigned to three groups. A spontaneous labour group $(n=4)$ was monitored and plasma samples were taken daily until spontaneous labour was established. A dexamethasone-induced labour group $(n=4)$ received a continuous fetal i.v. dexamethasone infusion $(1 \mathrm{mg} /$ day in sterile saline at $1 \mathrm{ml} / \mathrm{h})$ from 135 days GA (Grigsby et al. 2000). A saline-infused control group $(n=4)$ received a continuous saline infusion from 135 days GA. Fetal and maternal arterial and UOV blood samples $(4 \mathrm{ml})$ were obtained daily and after the commencement of the infusions at $14 \mathrm{~h}$ intervals and immediately prior to elective postmortem for $\mathrm{PGE}_{2}$ and $\mathrm{PGF}_{2 \alpha}$ assay. Samples were collected in iced tubes containing indomethacin $(10 \mu \mathrm{M} ; 10 \mu \mathrm{l} / \mathrm{ml}$ whole blood $)$ and EDTA $(15 \mu \mathrm{l}$ saturated solution/ml blood). Plasma was then divided into aliquots and immediately stored at $-20^{\circ} \mathrm{C}$. Aliquots for $\mathrm{PGE}_{2}$ analysis were diluted $1: 1$ with $0.12 \mathrm{M}$ methoxyamine hydrochloride in sodium 
Table 1 PGHS-2, PGFS and PGES primer characteristics

\begin{tabular}{|c|c|c|c|c|c|c|}
\hline & $\begin{array}{l}\text { Sequence } \\
\text { (forward and reverse) }\end{array}$ & $\begin{array}{l}\text { Accession } \\
\text { no. }\end{array}$ & $\begin{array}{l}\text { Product } \\
\text { size }(b p)\end{array}$ & $\begin{array}{l}\text { Annealing } \\
\text { temperature } \\
\left({ }^{\circ} \mathrm{C}\right)\end{array}$ & $\begin{array}{l}\mathrm{MgCl}_{2} \\
\text { concentration } \\
(\mathrm{mM})\end{array}$ & $\begin{array}{l}\text { RT } \\
\text { dilution }\end{array}$ \\
\hline \multicolumn{7}{|l|}{ Gene } \\
\hline PGHS-2 & $\begin{array}{l}\text { 5'-ctgtatcccgccettctggtag } \\
\text { 5'-tcggttgaacgctcctttagtag }\end{array}$ & U68486 & 346 & 65 & 3 & $1: 30$ \\
\hline PGFS & $\begin{array}{l}5 \text { '-ccaaatccatcggggtgt } \\
5 \text { '-tgctctggttgaggtaagggtg }\end{array}$ & AF257738 & 125 & 59 & 4 & $1: 20$ \\
\hline PGES & $\begin{array}{l}5^{\prime} \text {-tgtgtttccccgtgtgtc } \\
5^{\prime} \text {-actgagtctctgtttgcttttc }\end{array}$ & AY032727 & 169 & 54 & 3 & $1: 20$ \\
\hline
\end{tabular}

acetate buffer containing 10\% ethanol and incubated overnight at room temperature before being stored at $-20^{\circ} \mathrm{C}$.

\section{RNA extraction}

Total RNA was extracted using Qiagen RNeasy kits from $150 \mathrm{mg}$ snap-frozen myometrial, endometrial and placentome tissue according to the manufacturer's instructions. An additional On-Column DNase Digestion with RNase-Free DNase set (Qiagen) was performed to ensure digestion and complete removal of any contaminating DNA during RNA purification. High-quality $\left(\mathrm{OD}_{260 \mathrm{~mm}} /\right.$ $\left.\mathrm{OD}_{280 \mathrm{~nm}}>1.9\right)$ RNA was eluted in RNase-free water, stored at $-70{ }^{\circ} \mathrm{C}$ and its integrity confirmed by electrophoresis on a $1 \%$ agarose gel stained with ethidium bromide.

\section{Design of oligonucleotide primers}

Sense and antisense oligonucleotide primers for PGHS-2 and PGFS were designed from reported ovine sequences (Zhang et al. 1996b, Wu et al. 2001). The designs of PGES primers were based on reported bovine sequence (Filion et al. 2001). Netprimer (Premier BioSoft, Palo Alto, CA), Genefisher and Amplify software (University of Wisconsin, Madison, WI, USA) were used to design and optimize primers with stringency conditions of length (20-25 bp), melting temperature $\left(55-80{ }^{\circ} \mathrm{C}\right)$, GC content ( $\sim 50 \%)$, primer dimer formation and self-priming formation. BLAST was used to determine that the primers bound exclusively to the specific RNA of interest and primers were custom made by Sigma Genosys (Sydney, Australia).

\section{$R T-P C R$}

Total RNA $(2 \mu \mathrm{g})$ from myometrium, endometrium and placenta was reverse transcribed in a total reaction volume of $20 \mu \mathrm{l}$ containing $40 \mathrm{U}$ RNAase inhibitor, $250 \mathrm{ng}$ oligo-dT primer, $5 \times$ Expand Buffer (Roche Molecular),
$10 \mathrm{mM}$ dithiothreitol, $0.5 \mathrm{mM}$ dNTP $\operatorname{mix}$ and $50 \mathrm{U}$ Expand RT (Roche Molecular). RNA was first denatured at $70{ }^{\circ} \mathrm{C}$ for $10 \mathrm{~min}$, followed by $45^{\circ} \mathrm{C}$ for $50 \mathrm{~min}$ for the reverse transcription, and then $70{ }^{\circ} \mathrm{C}$ for $15 \mathrm{~min}$ to terminate the reaction. The $\mathrm{RT}$ product was stored at $-20{ }^{\circ} \mathrm{C}$ until required for use in real-time PCR.

Appropriate cDNAs to be used as standards in real-time PCR quantification were generated by conventional PCR on a thermal block cycler (PCR Express Machine; Thermo Hybaid, Ashford, Middlesex, UK) using corresponding primer pairs that were used in the real-time PCR quantification (Table 1). Each reaction tube contained $1 \mu \mathrm{l}$ 1:20 dilution of the reverse transcription product as template, $250 \mu \mathrm{M}$ each dNTP, $1.5 \mathrm{U}$ Taq polymerase, and $1 \mu \mathrm{M}$ each primer in $50 \mu \mathrm{l} 1 \times \mathrm{PCR}$ buffer (Roche Molecular). PCR reactions were first preincubated at $95^{\circ} \mathrm{C}$ for $5 \mathrm{~min}$, followed by 40 cycles of $30 \mathrm{~s}$ at $95^{\circ} \mathrm{C}$ (denaturing), annealing at specific temperatures for $30 \mathrm{~s}$ and $72{ }^{\circ} \mathrm{C}$ for $35 \mathrm{~s}$ (extension) and a final extension of $7 \mathrm{~min}$ at $72{ }^{\circ} \mathrm{C}$. PCR product for each gene was run on a $1.5 \%$ agarose gel-1 $\times$ TBE gel $(1 \times \mathrm{TBE}=89 \mathrm{mM}$ Tris-borate and $2 \mathrm{nM}$ EDTA, $\mathrm{pH}$ $8 \cdot 3$ ) alongside a $1 \mathrm{~kb}$ DNA ladder (Invitrogen) in order to verify product size. The product bands were then cut from the gel and DNA extracted using the QiaEx I Gel Extraction kit (Qiagen) and verified by sequencing (see below). Sequence-confirmed purified PCR products were used as standards in real-time PCR quantification. In all cases, the cDNA standards used were identical to the real-time PCR products to ensure equal amplification efficiency between standards and PCR products.

\section{Sequencing}

Purified PCR products were sequenced by the Wellcome Trust Sequencing Centre (Prince Henry's Institute of Medical Research and the Monash Institute of Reproduction and Development) using an ABI Prism TM 377 DNA Sequencer (Perkin-Elmer Biosystems, Foster City, CA, USA). Sequenced PCR products were verified against the nucleotide database using the National Centre 
for Biotechnology Information nucleotide-nucleotide BLAST search. All sequences showed high homology $(100 \%)$ to the published ovine sequence, or in the case of PGES the bovine sequence, thus confirming their identity.

\section{Real-time PCR}

Quantification of relative mRNA abundance for PGHS-2, PGFS and PGES was performed by real-time PCR amplification in a LightCycler (Roche) instrument using SYBR Green I fluorescence detection of amplified products. The primer pairs, optimal $\mathrm{MgCl}_{2}$ concentrations and the dilution of reverse transcription products used in the real-time PCR analysis are shown in Table 1. A $20 \mu \mathrm{l}$ PCR reaction was used and included LightCycler Fast Start DNA Master SYBR Green I $(2 \mu \mathrm{l}), 0 \cdot 5 \mu \mathrm{M}$ each primer, 2-5 mM $\mathrm{MgCl}_{2}$ (see Table 1) and reversed transcribed cDNA ( $2 \mu \mathrm{l}$ of the diluted RT products). For quantification, standard curves consisting of serial dilutions of the appropriate purified cDNAs were included. All reactions were set up in duplicate. Before PCR amplification, an initial denaturation $\left(10 \mathrm{~min}\right.$ at $\left.95^{\circ} \mathrm{C}\right)$ step was used. Cycle profile for the PCR amplification consisted of 40 cycles of a denaturation, annealing and elongation steps (specific conditions for each gene in Table 1). Following PCR, melting curve analysis $\left(55-99{ }^{\circ} \mathrm{C}\right.$ with a heating rate of $0.2{ }^{\circ} \mathrm{C} / \mathrm{s}$ and continuous fluorescence measurements were performed on the amplified products to ensure only specific PCR amplicons were obtained and quantified. This was also confirmed by size determination using agarose gel electrophoresis. Using the LightCycler Software $3 \cdot 5$, a standard curve was constructed based on the cycle number (crossing point) at which fluorescence (generated by the binding of SYBR Green I to the double-stranded DNA) exceeded the threshold for each standard. In this study, the second derivative maximum method was used to calculate the crossing point value for the standards and the samples. Data obtained from the LightCycler were normalized against $18 \mathrm{~S}$ ribosomal RNA, which was quantified by electrophoresing equivalent amounts of RNA $(0.6 \mu \mathrm{g})$ on an agarose gel and the $18 \mathrm{~S}$ ribosomal RNA fluorescence measured using a CCD camera with Quantity One $5 \cdot 1$ software (BioRad). All measurements were done within the linear range under non-saturating pixel conditions. The electrophoresed RNA was also used to confirm the integrity of all RNAs used in the real-time PCR analysis.

\section{Uterine EMG analysis and postmortem}

EMG activity was recorded on a Grass polygraph and the signal amplified using a Grass 7P3 amplifier with high pass filtering at $3 \mathrm{~Hz}$. The trace was analysed for frequency of bursts to determine myometrial contractility and labour onset during the $60 \mathrm{~h}$ prior to postmortem. The number of discrete bursts of uterine activity/2 $\mathrm{h}$ during this period was calculated as described previously (Grigsby et al. 2000). Ewes were killed during established labour or, in the case of the saline group, at a time-matched point with the dexamethasone-induced ewes (GA 137 days). Ewes were killed by a barbiturate overdose and the uteri quickly exteriorized. Samples of myometrium, endometrium and placentomes from the mid-section of the uterus were removed and immediately snap frozen in liquid nitrogen and stored at $-70{ }^{\circ} \mathrm{C}$ for subsequent RNA extraction.

\section{PG RIAs}

RIA of plasma samples for maternal and UOV $\mathrm{PGE}_{2}$ and $\mathrm{PGF}_{2 \alpha}$ were performed as described previously (McLaren et al. 1996). Maternal and UOV $\mathrm{PGE}_{2}$ and $\mathrm{PGF}_{2 \alpha}$ concentrations were analysed over the $120 \mathrm{~h}$ before postmortem. Sample times were grouped into blocks with means of $-117,-93,-69,-49,-35,-21,-7$ and $0 \mathrm{~h}$ (immediately prior to postmortem). The inter-assay coefficients of variation for $\mathrm{PGE}_{2}$ and $\mathrm{PGF}_{2 \alpha}$ were 12 and $15 \cdot 4 \%$ respectively; intra-assay coefficients of variation were 8 and $5 \cdot 6 \%$ respectively.

\section{Statistical analysis}

All data were tested for homogeneity of variance and transformed if necessary to achieve homogeneity. Plasma PG concentrations were analysed for the effect of treatment and time using ANOVA for repeated measures. Where significant treatment $\times$ time interactions were found, treatment groups were analysed individually and differences between means were detected by least significant differences (LSD) test. Differences in mean mRNA expression in tissues from control and in labour samples were analysed by one-way ANOVA and a subsequent LSD test. All analysis was conducted using SPSS-X (SPSS, Chicago, IL, USA). Data are presented as means \pm S.E.M. and significant differences reported at the $P<0.05$ level.

\section{Results}

\section{Timing to delivery}

All fetuses displayed normal blood gas parameters and were alive when the ewes were killed for tissue collection. Dexamethasone-induced and spontaneous labour ewes were killed during well-established labour, immediately prior to delivery of the fetus as indicated by a continuous contractile EMG activity pattern and presentation of the fetus at the cervix. For dexamethasone-induced ewes this was at $55 \cdot 4 \pm 3.0 \mathrm{~h}$ after the start of the dexamethasone infusion. Saline-treated ewes were time-matched with these ewes and were killed $55 \cdot 3 \pm 1 \cdot 2 \mathrm{~h}$ after the onset of the saline infusion. Ewes that were allowed to naturally progress into spontaneous labour were killed when the 
Placentome
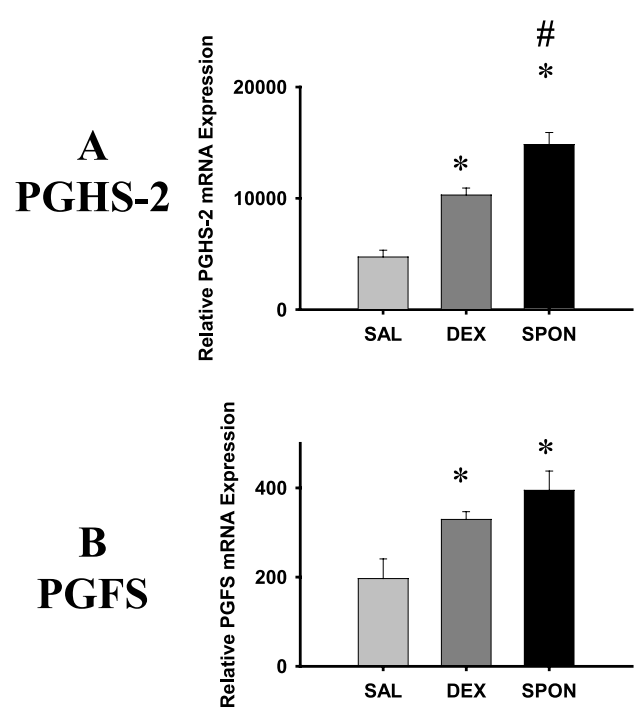

B PGFS

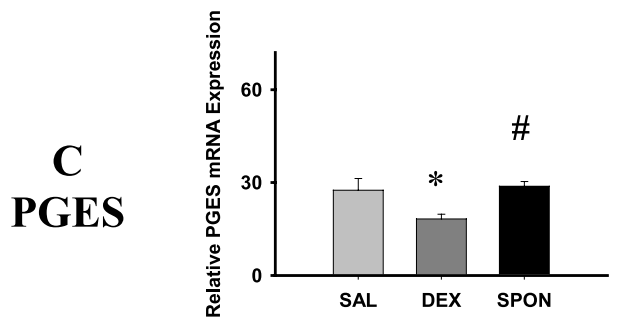

Endometrium
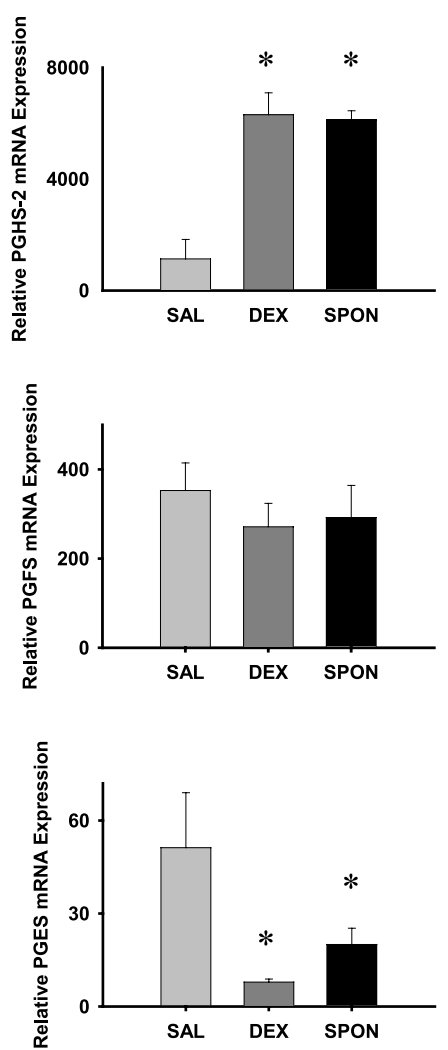

Myometrium
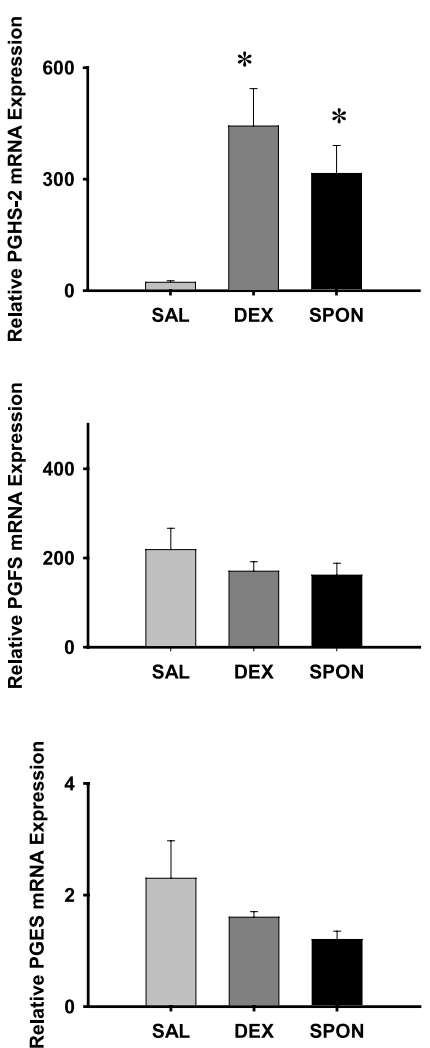

Figure 1 Relative mRNA abundance (means \pm S.E.M.) of (A) PGHS-2, (B) PGFS and (C) PGES in placentome, myometrium and endometrium of non-labour saline control (SAL, $n=4)$, dexamethasone-induced (DEX, $n=4)$ and spontaneous labour $(S P O N, n=4)$ ewes. Abundance of mRNA is expressed relative to $18 \mathrm{~S}$ mRNA. ${ }^{*} P<0.05$ vs SAL group; ${ }^{\#} P<0.05$ DEX vs SPON groups.

fetus presented at the cervix and this was at $146 \cdot 1 \pm 1 \cdot 3$ days of gestation.

\section{PG synthase expression}

The relative abundance of PGHS-2 mRNA in the placentome, endometrium and myometrium was markedly higher following dexamethasone-induced and spontaneous labour compared with values for saline-treated ewes $(P<0 \cdot 001)$ (Fig. 1A). PGHS-2 expression was also significantly higher following spontaneous labour compared with dexamethasone-induced labour in the placentome; however, there was no difference between the labouring groups for the endometrium and myometrium. Basal PGHS-2 expression as reflected by that seen in the non-labouring, saline-treated ewes at GA 137 days was significantly greater in the placentome compared with the endometrium $(P<0.001) \quad(8$-fold) and myometrium $(P<0 \cdot 001)$ (300-fold). In addition, the levels of expression achieved during dexamethasone-induced and spontaneous labour were also much greater in the placentome compared with the endometrium and myometrium (Fig. 1A).

The expression of PGFS was increased in the placentome following dexamethasone-induced and spontaneous labour onset $(P<0 \cdot 01)$, with no difference in the degree of upregulation of expression between these groups (Fig. 1B). However, there was no labour-associated change in PGFS expression in the endometrium and myometrium compared with values for the saline-treated animals. There was a significantly larger amount of PGFS mRNA in the endometrium of the saline-treated ewes when compared with the placentome $(P=0 \cdot 034)$. In order to determine if changes in PGFS expression occurred in association with labour onset in extrauterine tissues, expression was determined in maternal liver and lung tissue. There were no changes in PGFS expression following labour onset in these tissues (data not shown).

In contrast to PGFS, the expression of PGES fell significantly with dexamethasone-induced labour in the placentome $(P=0 \cdot 021)$ (Fig. 1C). However, placentomal 
expression of PGES did not change with spontaneous labour onset and remained significantly higher than levels in dexamethasone-treated ewes. PGES expression declined dramatically in the endometrium in association with dexamethasone-induced and spontaneous labour $(P=0.006$ and $P=0.039$ respectively), while expression in the myometrium did not change. Interestingly, the expression of PGES was markedly lower in the myometrium than in the endometrium of all three groups of animals $(P=0 \cdot 002)$.

\section{Veno-arterial differences in PG concentrations}

Veno-arterial differences in $\mathrm{PGF}_{2 \alpha}$ concentrations across the uterine vascular bed showed a significant effect of time $(P<0.001)$ and time $\times$ treatment interaction $(P=0.002)$ (Fig. 2A). Saline-control ewes showed no significant change, while dexamethasone-induced and spontaneous ewes showed a significant increase $21 \mathrm{~h}$ prior to postmortem $(P<0 \cdot 001)$. Veno-arterial differences in $\mathrm{PGE}_{2}$ concentrations showed no significant effect of time or treatment. The veno-arterial differences in the concentrations of the specific PGs closely reflect their intrauterine production and can be seen as an indirect measure of the terminal synthase enzyme activities.

\section{$P G F_{2 a}: P G E_{2}$ ratio in $U O V$ plasma}

The $\mathrm{PGF}_{2 \alpha}: \mathrm{PGE}_{2}$ ratio in UOV plasma is shown in Fig. 2C. There was a significant effect of time, treatment and time $\times$ treatment interaction. There was no increase in this ratio in the saline-infused control group. The dexamethasone-induced group showed a significant increase from $21 \mathrm{~h}$ prior to postmortem $(P=0.023)$. The spontaneous labour group showed a significant increase from $49 \mathrm{~h}$ prior to postmortem $(P=0.027)$ and a further increase $21 \mathrm{~h}$ prior to postmortem $(P=0 \cdot 028)$. These data indicate the increased production of $\mathrm{PGF}_{2 \alpha}$ over $\mathrm{PGE}_{2}$ in uterine plasma at the time of labour.

\section{Uterine EMG activity}

EMG activity records were analysed for the $60 \mathrm{~h}$ prior to postmortem (Fig. 3). Uterine electrical activity showed significant effects of time $(P<0 \cdot 001)$, treatment $(P=$ $0.009)$, and time $\times$ treatment interaction $(P<0.001)$. There was no effect of time in the saline-control ewes. The dexamethasone-induced and spontaneous labour groups showed a significant increase in uterine activity $16 \mathrm{~h}$ prior to delivery $(P=0 \cdot 017)$, with further increases $8 \mathrm{~h}(P=0 \cdot 001), 4 \mathrm{~h}(P=0 \cdot 002)$ and immediately prior to postmortem $(P=0 \cdot 045)$.

\section{Discussion}

This study is the first to compare the simultaneous expression of the terminal PG synthases responsible for the secretion of $\mathrm{PGE}_{2}$ and $\mathrm{PGF}_{2 \alpha}$ and PGHS-2 in gestational tissues of labouring and non-labouring ewes, and to relate these results to measures reflecting uterine PG secretion and electrical activity. These results indicate that the greatest capacity for $\mathrm{PG}$ production as reflected by PGHS-2 expression resides overwhelmingly in the placentome, and that the observed increase in the $\mathrm{PGF}_{2 \alpha}: \mathrm{PGE}_{2}$ ratio in UOV effluent is attributable to increased expression of placental PGFS at labour onset. The wet weights of the placenta and the remaining constituents of the uterine wall are roughly equivalent (307 and $442 \mathrm{~g}$ respectively) (Cloete 1939), and we found large quantities of PGHS-2 mRNA in the placenta vs the endometrium and myometrium. These observations support the contention that the placenta appears to be quantitatively the main site of intrauterine $\mathrm{PGF}_{2 \alpha}$ synthesis at labour with a rise in both PGHS-2 and PGFS expression contributing to the increased production of $\mathrm{PGF}_{2 \alpha}$.

Previous studies by Mitchell \& Flint (1978) have investigated the in vitro PG synthesis by fetal and maternal placental and myometrial tissue in the dexamethasoneinduced labour model. Using this in vitro system, PG production by the placental tissues exceeded that of the myometrium in late gestation. Our observations are in keeping with the previous results; the UOV $\mathrm{PGE}_{2}$ and $\mathrm{PGF}_{2 \alpha}$ concentrations that we observed agree well with their estimates of the relative production rates of $\mathrm{PGE}_{2}$ and $\mathrm{PGF}_{2 \alpha}$. However, in the previous studies increased production of $\mathrm{PGE}_{2}$ as well as $\mathrm{PGF}_{2 \alpha}$ was observed in association with labour. The reason for this discrepancy is unknown, but may reflect a difference between the expression or activity of synthases between the in vivo and in vitro conditions.

The temporal profile of uterine electrical activity was similar to that of UOV $\mathrm{PGF}_{2 \alpha}$, lagging behind it by approximately $12 \mathrm{~h}$, consistent with a pivotal role for $\mathrm{PGF}_{2 \alpha}$ in the regulation of uterotonic activity (Olson et al. 1985) and our recent finding that the selective inhibition of $\mathrm{PGF}_{2 \alpha}$ action markedly suppresses uterine activity (Olson 2003).

The PGFS enzyme that was measured in the present study is a 9,11-endoperoxide reductase (Watanabe et al. 1985). We have not specifically excluded a role for the enzyme PGE 9-ketoreductase, which catalyses the conversion of $\mathrm{PGE}_{2}$ to $\mathrm{PGF}_{2 \alpha}$; however, the activity of this enzyme is very low in gestational tissues (Niesert et al. 1986). Our observations suggest the marked increase in PGFS mRNA expression in the placentome, together with the very high expression of PGHS-2 and likely rise in the availability of $\mathrm{PGH}_{2}$ substrate, is primarily responsible for the labour-associated increase in $\mathrm{PGF}_{2 \alpha}$ production.

Wu et al. (2001) measured PGFS mRNA in the ovine myometrium and endometrium, and in maternal and fetal placenta. They found no change in PGFS mRNA levels in any of the tissues in response to spontaneous labour, while we found increased mRNA expression in the placentome. 
$\mathbf{A}$
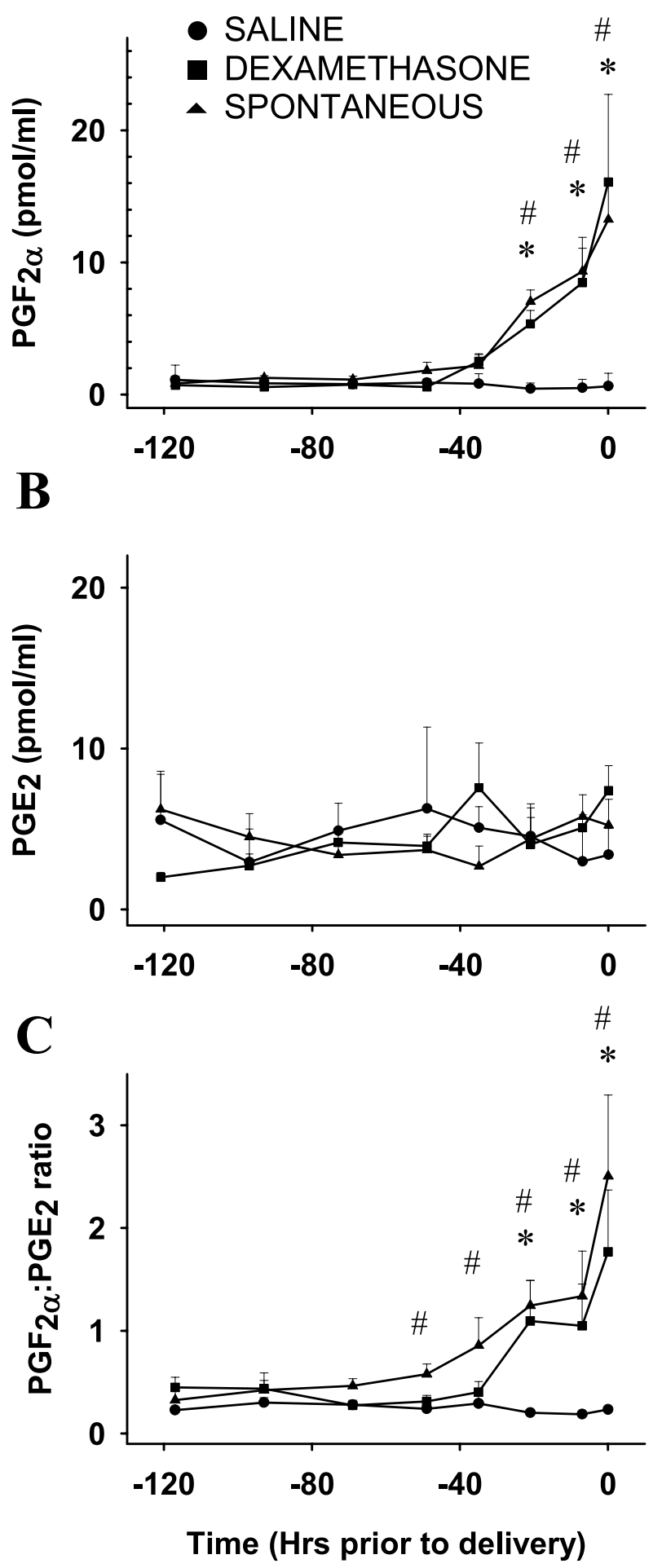

www.endocrinology.org
In betamethasone-induced labour, Wu et al. reported that PGFS mRNA levels were decreased in the endometrium and fetal placenta. In contrast, we detected an increase in placental PGFS mRNA expression in glucocorticoidinduced labour. The difference between these studies may reflect a difference between the analytical techniques used. Alternatively, betamethasone was used in the studies of $\mathrm{Wu}$ et al. and the difference between the glucocorticoid analogues used may have contributed to the disparity in the findings, as has been previously reported (Derks et al. 1996).

The PGFS enzyme expression that we measured has multiple metabolic roles and is expressed in the bovine lung and liver. Accordingly, to determine if upregulation was restricted to intrauterine tissues, we measured PGFS expression in the maternal lung and liver. The finding of no labour-associated change suggests that PGFS expression is selectively upregulated in placental tissue by fetal or local influences rather than maternal systemic factors.

The labour-associated increase we observed in PGHS-2 mRNA is consistent with previous studies showing increased PG synthase activity (Rice et al. 1988, Wimsatt et al. 1993), PGHS-2 mRNA (Wimsatt et al. 1993, Gibb et al. 1996, Wu et al. 1999, 2001) and protein (McLaren et al. 1996, 2000) in association with late gestation and labour in sheep. Wu et al. (2001) reported a significant increase in PGHS-2 mRNA in association with spontaneous term labour, but not with glucocorticoid-induced labour. We found increased PGHS-2 mRNA in both labour settings and we also confirmed that PGHS-2 expression was upregulated at labour in placental, endometrial and myometrial tissue (Wu et al. 2001). The large amount of PGHS-2 mRNA found in the placentome relative to the myometrium and endometrium is consistent with the PGHS-2 protein content reported by McLaren et al. (2000).

Although the placentome has the largest amount of PGHS-2 mRNA, it was the myometrium that exhibited the greatest relative increase in mRNA expression in association with labour. The relative importance for uterotonic activity of PGs derived from the placentomes or the myometrium remains unclear. PGs are known to diffuse out of the UOV to affect biological actions (Thorburn \& Nicol 1971), so we cannot exclude the possibility that uterotonic PGs may access the myometrium through the walls of the numerous veins that drain blood from the placentomes, traversing the myometrium. Alternatively, the large relative increase in PGHS-2 expression in the

Figure 2 (A) Veno-arterial differences in $\mathrm{PGF}_{2 \alpha}$ concentrations, (B) veno-arterial differences in $\mathrm{PGE}_{2}$ concentrations, and (C) $\mathrm{PGF}_{2 \alpha}: \mathrm{PGE}_{2}$ ratio in UOV plasma in non-labour saline control, dexamethasone-induced and spontaneous labour ewes. Means \pm S.E.M. Values from $120 \mathrm{~h}$ before postmortem until postmortem (time 0 ). ${ }^{*} P<0.05$ in the dexamethasone-induced group. ${ }^{\#} P<0.05$ in the spontaneous labour group. 


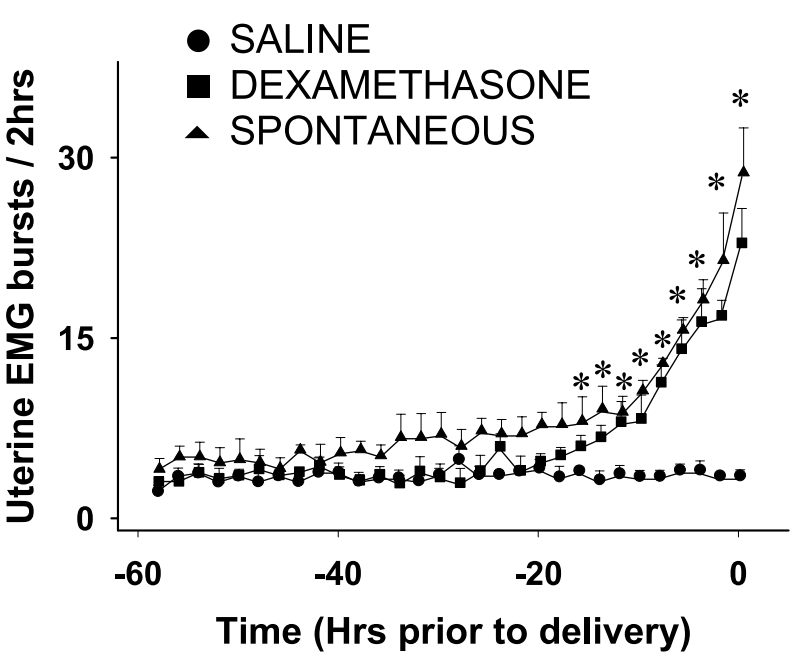

Figure 3 Uterine EMG activity during non-labour saline control $(n=4)$, dexamethasone-induced $(n=4)$ and spontaneous labour $(n=4)$ ewes. Means \pm S.E.M. Values from $60 \mathrm{~h}$ prior to postmortem until postmortem (time 0 ). ${ }^{*} P<0.05$ in dexamethasone-induced and spontaneous labour groups.

myometrium that occurs in association with labour may make available a larger pool of substrate for the terminal synthase enzymes in that tissue and lead directly to increased myometrial activity.

In this study we measured the expression of mPGES, which is the principal form expressed in ovine placentomes from 65 days gestation (Martin et al. 2002). Martin et al. (2002) reported that the expression of this enzyme is associated with PGHS-2 and increases with advancing gestation in the placenta. We found a marked labour-associated decrease in PGES expression in the endometrium and a corresponding, non-significant trend in the myometrium. However, the basal expression in the myometrium was extremely low, suggesting $\mathrm{PGE}_{2}$ production by this tissue only makes a minor contribution to circulating concentrations in plasma and within the uterine compartment. In the placenta, PGES expression was decreased in dexamethasone-induced labour, but not in spontaneous labour. The significance of these data is unclear, possibly reflecting a pharmacological effect of the synthetic glucocorticoid, although the lack of a similar effect in the myometrium and endometrium argues against this suggestion. Importantly, there was no increase in the expression of this enzyme in association with labour, in agreement with the finding by Martin et al. (2002) that ovine placental PGES mRNA did not increase at labour onset. Studies investigating PGES in bovine endometrium during the oestrous cycle suggest that PGES expression parallels the induction of PGHS-2 (Filion et al. 2001). However, a corresponding relationship between either PGES or PGFS and PGHS-2 was not seen in the current study as at the time of labour PGHS-2 expression was elevated in all tissues examined, whereas the expression of the terminal synthases rose, fell or were unchanged, depending on the tissue examined. These findings suggest that the expressions of these enzymes are regulated independently of PGHS-2 in this context.

The temporal profiles of $\mathrm{PGF}_{2 \alpha}$ and $\mathrm{PGE}_{2}$ in maternal plasma were consistent with the mRNA analyses inasmuch as the concentration and veno-arterial difference of $\mathrm{PGF}_{2 \alpha}$ increased while those of $\mathrm{PGE}_{2}$ did not. These findings may be viewed as in vivo bioassays reflecting the relative activities of the synthase terminal enzymes. The profiles of $\mathrm{PGF}_{2 \alpha}$ and $\mathrm{PGE}_{2}$ we observed were consistent with previous reports (Olson et al. 1985, Mclaren et al. 1996).

Both $\mathrm{PGF}_{2 \alpha}$ and $\mathrm{PGE}_{2}$ are uterotonic agents in vitro; however, the lack of any increase in both the concentration of $\mathrm{PGE}_{2}$ in UOV effluent and the mRNA encoding PGES suggests that increased $\mathrm{PGE}_{2}$ synthesis is not a principal regulator of uterine contractile activity in the sheep. The increase in fetal plasma $\mathrm{PGE}_{2}$ concentration during the progression of labour (McLaren et al. 1996) suggests a specific physiological role for this eicosanoid in the fetus, but how this increase is achieved is unclear. Unidirectional secretion from the placenta into the fetal circulation is a possibility, as is a decrease in $\mathrm{PGE}_{2}$ clearance from the fetal plasma or a non-placental source for the circulating $\mathrm{PGE}_{2}$. The design of the present study does not permit any distinction between these alternatives.

By simultaneously comparing their expression in key gestational tissues, this study clarifies the role of terminal PG synthases at the time of labour. PGFS expression was markedly elevated in the placentome at the time of labour, and this, together with increased PGHS-2 mRNA expression, most likely leads to the differential increase of plasma $\mathrm{PGF}_{2 \alpha}$ as reflected in the $\mathrm{PGF}_{2 \alpha}: \mathrm{PGE}_{2}$ ratio in UOV plasma. The decline or lack of change seen in PGES mRNA expression in the face of increased PGHS-2 mRNA expression may contribute to increasing the available $\mathrm{PGH}_{2}$ for $\mathrm{PGF}_{2 \alpha}$ production by PGFS. Thus the present finding indicates that upregulation of PGFS has a key role in the rise in $\mathrm{PGF}_{2 \alpha}$ concentrations and uterine activity at dexamethasone-induced and spontaneous labour onset in the sheep.

\section{Acknowledgements}

We would like to thank Alex Satragno for his surgical assistance.

\section{Funding}

This work was supported by a programme grant from the National Health and Medical Research Council of Australia. There is no conflict of interest that would prejudice the impartiality of this work. 


\section{References}

Carraher R, Hahn DW, Ritchie DM \& McGuire JL 1983 Involvement of lipoxygenase products in myometrial contractions. Prostaglandins 26 23-32.

Cloete JHL 1939 Prenatal growth in the merino sheep. Onderstepourt Journal of Veterinary Science and Animal Industry 13 417-557.

Deayton JM, Young IR \& Thorburn GD 1993 Early hypophysectomy of sheep fetuses: effects on growth, placental steroidogenesis and prostaglandin production. Journal of Reproduction and Fertility $\mathbf{9 7}$ 513-520.

Derks JB, Giussani DA, Van Dam LM, Jenkins SL, Winter JA, Zhao XF, Hammond GL \& Nathanielsz PW 1996 Differential effects of betamethasone and dexamethasone fetal administration of parturition in sheep. Journal of the Society for Gynecologic Investigation 3 336-341.

Filion F, Bouchard N, Goff AK, Lussier JG \& Sirois J 2001 Molecular cloning and induction of bovine prostaglandin $\mathrm{E}$ synthase by gonadotropins in ovarian follicles prior to ovulation. Journal of Biological Chemistry 276 34323-34330.

Gibb W, Matthews SG \& Challis JRG 1996 Localization and developmental changes in prostaglandin $\mathrm{H}$ synthase (PGHS) and PGHS messenger ribonucleic acid in ovine placenta throughout gestation. Biology of Reproduction 54 654-659.

Grigsby PL, Poore KR, Hirst JJ \& Jenkin G 2000 Inhibition of premature labor in sheep by a combined treatment of nimesulide, a prostaglandin synthase type 2 inhibitor, and atosiban, an oxytocin receptor antagonist. American Journal of Obstetrics and Gynecology 183 649-657.

Hirst JJ, Teixeira FJ, Zakar T \& Olson DM 1995 Prostaglandin endoperoxide- $\mathrm{H}$ synthase-1 and -2 messenger ribonucleic acid levels in human amnion with spontaneous labor onset. Journal of Clinical Endocrinology and Metabolism 80 517-523.

Jakobsson P, Thoren S, Morgenstern R \& Samuelsson B 1999 Identification of human prostaglandin E synthase: a microsomal, glutathione-dependent, inducible enzyme, constituting a potential novel drug target. PNAS 96 7220-7225.

Kujubu DA, Fletcher BS, Varnum BC, Lim RW \& Herschman HR 1991 TIS10, a phorbol ester tumor promoter-inducible mRNA from Swiss 3T3 cells, encodes a novel prostaglandin synthase/cyclooxygenase homologue. Journal of Biological Chemistry 266 12866-12872.

Liggins GC \& Grieves S 1971 Possible role for prostaglandin $\mathrm{F}_{2 \alpha}$ in parturition in sheep. Nature 232 629-631.

Liggins GC, Fairclough RJ, Grieves SA, Kendall JZ \& Knox BS 1973 The mechanism of initiation of parturition in the ewe. Recent Progress in Hormone Research 29 111-159.

Martin RL, Whittle WL, Holloway AC, Gyomery S, Gibb W, Lye SJ \& Challis JRG 2002 Ontogeny and regulation of ovine placental prostaglandin $\mathrm{E}_{2}$ synthase. Biology of Reproduction 67 868-873.

McLaren WJ, Young IR, Wong MH \& Rice GE 1996 Expression of prostaglandin $\mathrm{G} / \mathrm{H}$ synthase-1 and -2 in ovine amnion and placenta following glucocorticoid-induced labour onset. Journal of Endocrinology 151 125-135.

McLaren WJ, Young IR \& Rice GE 2000 Localisation and temporal changes in prostaglandin $\mathrm{G} / \mathrm{H}$ synthase- 1 and -2 content in ovine intrauterine tissues in relation to glucocorticoid-induced and spontaneous labour. Journal of Endocrinology 165 399-410.

Mitchell MD \& Flint APF 1978 Prostaglandin production in intra-uterine tissues from periparturient sheep: use of a superfusion technique. Journal of Endocrinology 76 111-121.

Murakami M, Naraba H, Tanioka T, Semmyo N, Nakatani Y, Kojima F, Ikeda T, Fueki M, Ueno A, Oh-ishi S et al. 2000 Regulation of prostaglandin $\mathrm{E}_{2}$ biosynthesis by inducible membrane-associated prostaglandin $\mathrm{E}_{2}$ synthase that acts in concert with cyclooxygenase-2. Journal of Biological Chemistry 275 32783-32792.

Niesert S, Christopherson W, Korte K, Mitchell MD, MacDonald PC \& Casey ML 1986 Prostaglandin E2 9-ketoreductase activity in human decidua vera tissue. American Journal of Obstetrics and Gynecology 155 1348-1352.

Olson DM 2003 Myometrial activation and preterm labour: evidence supporting a role of the prostaglandin $\mathrm{F}$ receptor $-\mathrm{a}$ review. Placenta 24 S47-S54.

Olson DM, Lye SJ, Skinner K \& Challis JRG 1985 Prostanoid concentrations in maternal/fetal plasma and amniotic fluid and intrauterine tissue prostanoid output in relation to myometrial contractility during the onset of adrenocorticotropin-induced preterm labor in sheep. Endocrinology 116 389-397.

Poore KR, Young IR \& Hirst JJ 1999 Efficacy of the selective prostaglandin synthase type 2 inhibitor nimesulide in blocking basal prostaglandin production and delaying glucocorticoid-induced premature labor in sheep. American Journal of Obstetrics and Gynecology 180 1244-1253.

Rice GE, Wong MH \& Thorburn GD 1988 Gestational changes in prostaglandin synthase activity of ovine cotyledonary microsomes. Journal of Endocrinology 118 265-270.

Rice GE, Freed KA, Aitken MA \& Jacobs RA 1995 Gestational- and labour-associated changes in the relative abundance of prostaglandin G/H synthase-1 and -2 mRNA in ovine placenta. Journal of Molecular Endocrinology 14 237-245.

Thorburn GD \& Nicol DH 1971 Regression of the ovine corpus luteum after infusion of prostaglandin $\mathrm{F}_{2 \alpha}$ into the ovarian artery and uterine vein. Journal of Endocrinology 51 785-786.

Watanabe K, Yoshida R, Shimizu T \& Hayaishi O 1985 Enzymatic formation of prostaglandin $\mathrm{F}_{2 \alpha}$ from prostaglandin $\mathrm{H}_{2}$ and $\mathrm{D}_{2}$. Journal of Biological Chemistry 260 7035-7041.

Watanabe K, Kurihara K \& Suzuki T 1999 Purification and characterization of membrane-bound prostaglandin E synthase from bovine heart. Biochimica et Biophysica Acta 1439 406-414.

Wimsatt J, Nathanielsz PW \& Sirois J 1993 Induction of prostaglandin endoperoxide synthase isoform-2 in ovine cotyledonary tissues during late gestation. Endocrinology 133 1068-1073.

Wiqvist N, Lindblom B, Wikland M \& Wilhelmsson L 1983 Prostaglandins and uterine contractility. Acta Obstetricia et Gynecologica Scandinavica. Supplement 113 23-29.

Wu WX, Xiao HM \& Nathanielsz PW 1999 Tissue-specific ontogenic expression of prostaglandin $\mathrm{H}$ synthase 2 in the ovine myometrium, endometrium, and placenta during late gestation and at spontaneous term labor. American Journal of Obstetrics and Gynecology 181 1512-1519.

Wu WX, Ma XH, Yoshizata T, Shinozuka N \& Nathanielsz PW 2001 Increase in prostaglandin $\mathrm{H}$ synthase 2, but not prostaglandin $\mathrm{F}_{2 \alpha}$ synthase mRNA in intrauterine tissues during betamethasone-induced premature labor and spontaneous term labor in sheep. Journal of the Society for Gynaecologic Investigation 8 69-76.

Zhang QI, Wu WX, Brenna JT \& Nathanielsz PW 1996a The expression of cystolic phospholipase A2 and prostaglandin endoperoxide synthase in ovine maternal uterine and fetal tissues during late gestation and labor. Endocrinology 137 4010-4017.

Zhang V, O'Sullivan M, Hussain H, Roswit WT \& Holtzman MJ $1996 b$ Molecular cloning, functional expression, and selective regulation of ovine prostaglandin $\mathrm{H}$ synthase-2. Biochemical and Biophysical Research Communications 227 499-506.

Received 30 October 2003

Accepted 9 December 2003 